УДК 81:316.346.2] (477)

Н. Д. Ковальчук, д. фрілос. н., профресор, Н. В. Шакун, к. філос. н., доцент, О. Є. Мельник, к. фрілос. н., доцент

\title{
КОНОТАЦІЇ КОНЦЕПТІВ ҐЕНДЕРУ І СТАТІ У ФЕМІНІСТИЧНИХ СТУДІЯХ
}

Актуальність теми дослідження. Культурні концепти гендер і стать, залишаючись домінантними у феміністичних студіях, здійснили суттєвий вплив на дослідження соціальних практик.

Постановка проблеми. Смислове наповнення понять «ґендер» $i$ «стать» ґрунтується на підході соціального конструктивізму, в основі якого лежить твердження про опосередкований вплив біологічних статевих відмінностей на соціальний статус та соціальну детермінацію біологічної інтрпретації.

Аналіз останніх досліджень і публікацій. Роботи таких вітчизняних і зарубіжних вчених, як О.Афранасьєва, М. Богачевська, Н. Зборовська,Г. Храброва, С. .д'Бовуар, Маєрчик, М. С. Окін, Л. Стоун, присвячені дослідженням культурних концептів ґендеру і статі.

Виділення недосліджених частин загальної проблеми. Здійснено спробу дослідити аксіологічну та символічну структуру феміністичного дискурсу шляхом аналізу змісту його ключових концептів.

Постановка завдання. Метою статті є аналіз конотації концептів гендеру і cmami y фокусі фреміністичних студій, які артикулюють відмінності «чоловічого» $i$ «жіночого», рівність можливостей чоловіків i жінок, висвітлюють роль соціальних інститутів у форомуванні ґендерної ідентичності.

Виклад основного матеріалу. Феміністична критика надає характеристику ролі чоловіка $i$ жінки в культурі, прагне створити картину соціальної дійсності, інтерпретуючи ї найважливіші параметри: «стать», «гендер», «тіло», «маскулінне», «фремінне». Вихідним положенням фоемінізму стає твердження про зануреність людини у світ культури і соціальних відносин, а відтак - потребу деконструкції класичної дихотомічної концептуально моделі, в яких «чоловіче» $i$ «жіноче» мають конотації вище-нижче, надійне-непередбачуване, сильнеслабке, активне-пасивне, культура-природа.

Висновки. Аналіз концептосфрери понять ґендеру та статі в феміністських студіях надає широкі можливості для конструювання картини соціальної дійсності та переосмислення культури.

Ключові слова: стать; концепт; фемінізм; тіло; ґендерна ідентичність.

N. D. Kovalchuk, Doctor of Philosophical Sciences, Professor,

N. V. Shakun, Candidate of Philosophical Sciences, Associate Professor,

O. Ye. Melnik, Candidate of Philosophical Sciences, Associate Professor

\section{CONOTATIONS OF GENDER AND SEX CONSEPTS IN FEMINIST STUDIOS}

Urgency of the research. While remaining dominant in feminist studies, cultural concepts of gender and sex have made a significant impact on research on social practices.

Target setting. The semantic content of the concepts of "gender" and "sex" is based on the approach of social constructivism, which is based on the statement about the indirect influence of biological sex differences on social status and social determination of biological interpretation.

Actual scientific researches and issues analysis. The works by such domestic and foreign scientists as O. Afanasieva, M.Bogachevska, N. Zborovska, H. Khrabrova, S. de. Beauvoir, M. Maierchyk, S. Okin, L. Stone and other are devoted to issues of cultural concepts of gender and sex. 
Uninvestigated parts of general matters defining. An attempt to explore the axiological and symbolic structure of women's discourse by analyzing the content of its key concepts was made.

The research objective is to analyze the connotations of the concepts of gender sex in the focus of feminist research, which articulates the distinctions of "male" and "female", equality of opportunities for men and women, highlight the role of social institutions in the formation of gender identity.

The statement of basic materials. Feminist criticism provides a description of the role of men and women in culture, aims to create a picture of social reality, interpreting its most important parameters: "gender", "sex", "body", "masculine", "feminine". The starting point of feminism is the assertion about the immersion of man in the world of culture and social relations, and hence the need for the deconstruction of the classical dichotomous conceptual model in which "male" and "female" have connotations above-below, reliable-unpredictable, strong-weak, active-passive, culture-nature.

Conclusions. Analysis of the conceptual sphere of the concepts of "gender" and "sex" in feminist studies provides wide opportunities for constructing a picture of social reality and culture rethinking.

Keywords: gender; sex; concept; feminism; body; gender identity.

DOI 10.25140/2412-1185-2018-1(13)-13-20

Актуальність теми дослідження. В умовах бурхливих соціальних трансформацій небиякої актуальності набуває трансдисциплінарний аналіз культурних механізмів соціальної взаємодії та ідентифрікації особистості. Змістовна спрямованість сучасних наукових дискусій зміщується $з$ обговорення абстрактних філософрсько-теологічних і соціобіологічних опозицій духовного і тілесного в людині до аналізу механізмів панування і гноблення, пов'язаних зі статевими рольовими установками особистості. Останній здійснюється у феміністичних студіях, які набули суттєвого піднесення у другій половині $\mathrm{XX}$ ст. і зробили рішучу спробу покласти край спробам пояснювати культурну різницю між чоловіками і жінками біологічними чинниками.

Постановка проблеми. Ядро феміністичного дискурсу утворюють. концепти ґендеру і статі. Ґендер (анг. gender - рід) - соціальний, культурно обумовлений аспект статі (на відміну від біологічного аспекту - анг. sex). Термін вперше вжив Роберт Столлер (Robert Stoller) в кін. 60-х років XX ст. для позначення культурних характеристик чоловіків та жінок на відміну від статі як сукупності біологічних характеристик особи.

Розрізнення ґендеру і статі мало важливе методологічне значення, оскільки сформувало уявлення про соціальну конструкцію статі як елемента культури і соцільної стратифікації. Першою працею, присвяченою аналізу ґендеру і статі як системи угод, якими суспільство трансформує біологічну сексуальність у продукт людської активності, стала робота Ґ. Рабіна (Rubin) «Обмін жінками» (1947р.). Остаточному розмежуванню цих понять сприяла праця Роди Унґер (Unger), «Про редефініцію понять статі і ґендеру». У значно ширший, соціальний, контекст гендер вводить Т. Парсонс, який зауважив зв'язок між особистими і суспільними структурами на основі концепту статевих ролей шляхом виокремлення моделей чи зразків, що $\epsilon$ основою різних соціальних ролей жінок і чоловіків і не можуть бути пояснені апеляцією до біологічних даних.

Аналіз останніх досліджень та публікацій. Феміністичний дискурс представлений множиною різноманітних концепуальних підходів, які стали предметом дослідження вітчизняних (М. Богачевська, Т. Говорун, Н. Зборовська, О. Кікінежді, О. Кісь, Т. Марценюк, С. Павличко, Н. Пушкарьова, М. Рудницька, Н. Чухім, Т. Семашко, Г. Храброва) та зарубіжних (Дж. Батлер, Ш. Берн, В. Брайсон, С .д’Бовуар, А. Ґраффф, Е. Кемпбел, Е. Кеслер-Херіс, Р. Колінз, Н.-К. Матьє, Р. Мерфін, С. Ходжсон-Райт Е. Шварцер, Н. Фрезер, С. Окін та ін.) науковців.

Аналізуючи різноплановість феміністичних студій, дослідники виокремлюють ліберальний, соціалістичний, марксистський, радикальний феемінізм [1]. Ліберальний підхід (Сьюзен Ентоні (Susan Anthony), Люсі Стоун (Lucy Stone), Елізабет Кеді Стентон (Elizabeth Cady Stanton), Еліс Pocci (Alice Rossi), Джанет Редкліф Річардс (Janet Radcliffe Richards), Сьюзен Моллер Оукін (Susan Moller Okin) та ін.), основу якого утворили теорії суспільного договору ті природних прав людини, наголошує на потребі забезпечення жінкам однакових з чоловіками прав та умов самореалізації. Ключовою ідеєю соціалістичного підходу (Джулієт Мітчелл (Juliet Mitchell), Шейла Рауботен (Sheila Rowbothan) Зілла Айзенштайн (Zillah Eisenstein), витоки якого містяться 
в роботах К. Маркса, Ф. Енгельса, є твердження, що гноблення жінок у суспільстві однаковою мірою залежить як від класової структури, так і від статевої опозиції. Марксистський підхід (Марія Роза Дала Коста (Maria Rosa Dalla Costa) наголошує, що саме соціальна структура суспільства (наявність класів) зумовлює статус і функції жінки та розглядає гноблення жінок як продукт політичної, соціальної й економічної структур, породжених капіталістичною системою. Радикальний підхід у феміністичних студіях (Суламіфь Файєрстоун (Shulamith Firestone) Кейт Міллет (Kate Millett) Мерилін Френч (Marilyn French), Шварцер Еліс (Schwarzer Alic), акцентує дискримінацію жінки за ознакою статі (сексизм) як наслідок домінування чоловіків над жінками та здійснює аналіз засобів та інститутів чоловічого домінування. Зауважимо, що спільною рисою всіх підходів стає вихідний принцип фемінізму: переконання у необхідності перегляду логоцентричного, патріархального характеру культури як культури ідеологічно маскулінної.

Плюральність наявних підходів пов'язана з різноманіттям філософсько-методологічних засад фемінізму: екзистенціалізм (С. де Бовуар, Ж-П. Сартр), психоаналіз (Дж. Мітчел, Ж. Грір, Н. Ходоров), постмодернізм (Л. Ірігарей, С Кофман, Ю. Крістева), структуралізм (Ф. де Соссюр), постструктуралізм (М. Фуко), соціальний конструктивізм (П. Бергер, Т. Лукман), символічний інтеракціонізм (І. Гофмман). В центрі феміністичних досліджень перебуває значне коло проблем: від ролі жінки в історії, літературі, культурі до співвідношення маскулінного та фремінного, рівності можливостей чоловіків і жінок, статусу жінки в патріархальному суспільстві тощо.

Виділення недосліджених частин загальної проблеми. Попри значне піднесення феміністичних студій, малодослідженою лишається аксіологічна та символічна структура феміністичного дискурсу. Аналіз конотацій концептів ґендеру і статі дасть можливість дослідити зміну їх змістовного наповнення в конкретно-історичних умовах, проаналізувати модифікацію концептуального поля сучасних феміністичних досліджень.

Постановка завдання: Метою статті $€$ здійснення аналізу конотації концептів ґендеру і статі у фокусі феміністичних досліджень, де останні виступають у якості тексту, структуру якого утворюють культурні знаки чи коди (концепти). Досягнення мети передбачає реалізацію трьох основних дослідницьких завдань. По-перше, дослідити аксіологічну та символічну структуру феміністичного дискурсу шляхом аналізу змісту його ключових концептів. По-друге, проаналізувати еволюцію концептів ґендер та стать в феміністських студіях. По-третє, виявити особливості модифікації їх концептосфери на сучасному етапі розвитку соціогуманітарного знання та встановити евристичні можливості концептів ґендер та стать для конструювання картини соціокультурної дійсності.

Виклад основного матеріалу. Історія виникнення фемінізму як доктрини сягає своїм коріннім у XVIII ст. Щодо виникнення терміну «фемінізм» та впровадження його у науковий i суспільний обіг, одностайності не існує Прихильники першого підходу пов'язують запровадження терміну «фемінізм» $з$ імям Александра Дюма-сина, адепти другого стверджують, що у обіг його ввів соціаліст-утопіст Ш. Фур'є, а третя версія конструювання терміну відсилає до теоретика утопічного соціалізму Р. Оуена.

Сучасні дослідники [2, с.18] виокремлюють три основні етапи фемінізму. Перший етап артикуляції проблеми статевої рівності тривав з XIX до першої половини XX ст. i характеризувався вимогами виборчих прав для представників різних статей та появою перших інститутів громадянського суспільства. Основні представники фемінізму «першої хвилі»: Гаррієт Тейлор (Harriet Taylor), Джон Стюарт Мілль (John Stuart Mill), Лідія Беккер (Lydia Becker), Еммелін Панкхьорст (Emmeline Pankhurst), Ема Голдман («Червона Ема») (Emma Goldman) та інші Цей етап ознаменувався діяльністю суфражисток, які започаткували політичні дискусії щодо рівноправ'я чоловіків і жінок, котрі згодом перемістились в ідеологічну та фрілософську площину.

Другий етап розвитку фемінізму припадає на 60-70-ті рр. XX ст. і супроводжувався появою численних жіночих рухів та виокремленням різноманітних течій феміністичних студій: соціалістична та марксистська (Дж. Мітчел, Е. Оуклі, Г. Гартман, Г. Гартсок, Л. Гордон), ліберально-демократична (С. де Бовуар, Б. Фрідан, Г. Стайнем), радикальна (К. Міллетт, М. К. Дельфі, Л. Іригарей, Е. Голдман, С. Файєрстоун) та ін. Основоположницею та теоретиком фемінізму «другої хвилі» вважається Сімона де Бовуар завдяки власній праці «Друга стать» (1949). В цій роботі дослідниця робить наголос на виключно біологічній природі статі та обґрунтовує громадську і культурну різниці між статями Поняття ґендеру обґрунтоване ідеєю, 
що стать є суто біологічним показником, інакше кажучи, існує громадська і культурна різниця між статями [3].

Протягом третього етапу розвитку фемінізму, який розпочався у 1980-х рр., відбувається остаточне формування фемінізму як аналітичного підходу до осягнення соціальної реальності 3 урахуванням її плюральності. Фемінізм «третьої хвилі» (неофемінізм) - бере свій початок із ранніх 90-х років XX століття і триває досі. Авторкою цього терміну стала американська письменниця Ребекка Уолкер, праця якої «Бути реальним. Поговоримо про сутність та зміну обличчя фемінізму» (Тo Be Real: Telling the Truth and Changing the Face of Feminism) (1995) стала своєрідною декларацією цього напряму в США.

В центрі феміністичних студій опнилося широке коло проблем: природа жіночого тексту та жіночої історії, патріархальні канони та стереотипні уявлення, нові гендерні ролі, гендерний порядок, гендерна рівність, гендерна дискримінація тощо. Завдяки зусиллям фреміністок, смислове поняття «гендер» деталізуються через призму контекстуальних дихотомій: (гендерна) рівність-нерівність, (гендерна) чутливість-нечутливість, (гендерний) баланс-дисбаланс тощо. Культурні концепти гендер і стать, залишаючись домінантними у феміністичних розвідках, справили суттєвий вплив на подільший розвиток міждисциплінарних досліджень гендеру, а отже, потребують уважного прочитання.

Термін «ґендер» (genre, gendre) та похідні від нього терміни «ґендерна рівність», «ґендерні стереотипи», «ґендерна ідентичність», «ґендерне інтегрування» (gender mainstreaming) тощо активно входять у науковий обіг з кінця $\mathrm{XX}$ ст. і широко вживаються в сучасних феміністичних студіях. Прикметно, що до 1960-х років XX ст. поняття «ґендер» вживалось переважно лінгвістами виключно для позначення граматичного роду. Сплеск гендерних досліджень припадає на 80-ті рр., коли з'являються такі визначення ґендеру, як «співвідношення людей різної статі», «соціальний конструкт статі», «організована модель соціальних стосунків між жінками і чоловіками». Причому останні десятиліття XX ст. ознаменувались появою різноманітних підходів дослідження статі і ґендеру, що свідчило про масштабність і складність цих френоменів. Зокрема, ґендер почали трактувати як сукупність домовленостей, завдяки яким суспільство перетворює біологічну сексуальність у результат активності людини (Г. Рубін) як організовану модель соціальних стосунків між статями, в основі яких лежить сприйняття міжстатевих відмінностей, (Д. Скотт), як культурний символ або метафору (Х. Сису ), як ідеологічний конструкт (Б. Фрідан), як механізм соціального впорядкування та засіб досягнення соціальної справедливості (Н. Фрезер).

Дослідження процесів конструювання ґендеру тісно пов'язане 3 проблемою залежності людини від соціокультурного середовища Розрізнення статі і ґендеру означало перехід від традиції пояснювати культурні відмінності між жінками і чоловіками біологічними чинниками до можливості пояснювати цю різницю соціальними й культурними детермінантами. Зміст ґендеру розкривався через аналіз системи міжособистісної взаємодії, що контролюється суспільством і відтворює уявлення про чоловіче і жіноче як категорії соціального, а не біологічного порядку. Концепти ґендеру і статі стали відображенням емоційного та логічного змісту феміністської дискусії щодо ролі біології в конституюванні гендерних відмінностей, результатом якої стало формування двох основних світоглядно-методологічних підходів: соціального конструктивізму та біологічного есенціалізму.

Соціальний конструктивізм наполягає на тому, що біологічні і статеві відмінності лише опосередковано впливають на статус жінки, а самі біологічні інтерпретації детерміновані суспільством. Концепт ґендеру відображає таким чином, складну соціальну взаємодію статеворольових стереотипів, біологічної статі та «гендерного дисплею», як сукупності різноманітних проявів, які пов'язані із закладеними у соціумі нормами фемінної та маскулінної взаємодій [4, с. 208]. Біологічний есенціалізм жіночі «відмінності» трактує як реальні характеристики, що визначають вороже до неї ставлення у світі, в якому домінують чоловіки [5]. I хоча жодними теоретичними даними це твердження не доведено, у багатьох наукових працях акцент на анатомобіологічних відмінностях між чоловіком і жінкою зберігається. Як з прикрістю констатують сучасні американські дослідники «комбінація статевих хромосом і статевих гормонів буквально надала чарівну силу прагненню фрормувати людську поведінку в ґендерному відношенні: жінки тепер опинились у милості своєї генетичної обмеженості і мінливого набору гормональних імперативів» [6, с. 20]. Біологічні пояснення залишаються широко визнаними 
завдяки загальному престижу «наук» і тому і ще тому, що дають широке виправдання існуючому порядку і охороняють привілеї тих, хто від них виграє [7, 48-52]. Осмислення причинних зв'язків між біологією і суспільством поглиблювали проблематичність розмежування природи та культури. I саме концепт ґендеру, як один з багатьох культурних кодів, втілив складну взаємодію природи і суспільства, щоразу наповнюючись новим значенням, розширюючи свої змістові конотації в конкретних культурно-історичних реаліях.

Змістовне наповнення концептів ґендер та стать в кінці $X X$ ст. розширилось завдяки піднесенню інтересу науковців до проблеми залежності людини від соціокультурного середовища. Важливу роль для формування вектору тогочасних соціогуманітарних досліджень відігравав культурологічний поворот, який відбувся у кінці XX ст., мав значний теоретикометодологічний потенціал і відкрив практичні можливості для фрілософії тілесності та гендерних досліджень. Культурологічний поворот ознаменував перехід від амбівалентного тлумачення тілесності («душа» і «тіло») до сприйняття тіла в культурно-ментальному плані, тобто крізь призму цінностей, притаманних певному суспільству. Застосовуючи соціокультурний підхід в дослідженнях соціальної взаємодії індивідів, культурологи підкреслювали взаємопроникнення культури в соціальність і акцентували багатомірність єдності особистого, соцієтального і культурного начал: «культура вписана в тіло. Наші уявлення про нього буквальні і символічні, соціальні. Тіло вигадане. Те, як ми тримаємось, одягаємось, виказує нашу приналежність до певної культури. В той же час і культура виникає з тіла [8, с. XVII].

Концепт ґендеру отримує нові аксіологічні виміри завдяки дослідницькій увазі до феномену тіла, який тривалий час перебував поза соціогуманітарним дискурсом. Потреба пізнання тіла як френомену не лише біологічного, а й культурного, соціального, історичного зумовила трансформацію фрілософського, релігійного, медичного дискурсу і дозволила по-новому осягнути співвідношення природи та культури, локального та глобального, чоловічності та жіночності, духу та плоті. У феміністичних студіях проводиться думка про те, що ототожнення жінки виключно з тілом та його функціями (народження та сексуальність) властиве традиційній культурній парадигмі. У зв'язку з цим традиційною сферою діяльності жінки вважалась сім'я, а основною формою її духовної реалізації визнавалась турбота про членів свої сім'ї. За влучним висловом Ніли Зборовської [9, с. 24], «у культурному проекті людини стосунки між статями спокон віків займали вагоме місце. Традиційний спосіб описання чоловічо-жіночої проблематики, коли жіноче означало пасивне, природнє, а звідси статеве, сексуальне (жінка власне вважалась єдиним представником статі), а чоловіче - активне, духовне, отож культурне та загальнолюдське , має давню і досить живу традицію».

Натомість у феміністичних студіях феномен тіла займає вагоме місце, деталізується культурними характеристиками, тлумачиться в культурно-ментальному, знаково-комунікативному плані: «тіло - це засіб par excellence сучасного індивіда досягти гламурного способу життя. Тіла більше не $є$ виразом того, як ми пристосувались до соціального порядку, а я способом самовираження, перетворення на тих, ким ми воліємо стати. В епоху, коли кожен сам відповідає за власну долю, тіло - лишень ще одна риса у власному пошуку ідентичності» [10, с. 2].

Аналізуючи сучасний соціокультурний контекст артикуляції тілесності, теоретики фемінізму не виявляють одностайності і доходять протилежних висновків. Ідеться про те, що на думку одних науковців (К. Девіс), тіло прийшло в соціальні науки завдяки переходу від індустріального до споживацького суспільства і зміни етичних цінностей, а тому концепт «сучасного тіла» породжений індивідуалізмом та культурою споживацтва. Інші (К. Лекрой) дотримуються протилежної думки за якою виникнення «культу тіла» свідчить про занепад індивідуалізму і зародження небезпечних форм соціальної колективності, оскільки «невдоволеність власним тілесним виглядом може мати серйозні психологічні наслідки для дівчат. Багато з них впевнені, що не зможуть нічого вчитини, в результаті у них розвивається відчуття безпорадності і безнадійності в поєднанні з низьким рівнем самооцінки і депресією» [11, с. 30].

Необіхідно підкреслити, що під впливом культурологічних розвідок відбувається постійна модифікація концептуального поля ґендеру. На зміну дихотомії природне-соціальне тіло приходить його плюралістична інтерпретація. Скажімо, американські культурологи (С. іДж. Хетті.) в залежності від сприйняття тіла, виокремили такі його типи: гендерне, сексуальне, медикалізоване, картезіанське, гротескне і сучасне [12, с. 3-25]. Беручи до уваги дану типологізацію, спробуємо розкрити зміст концептів ґендерне тіло, сексуальне тіло, 
медикалізоване тіло, гротескне тіло, сучасне тіло та виявити характер їх вживання у феміністичних розвідках. Зокрема, концепт ґендерного тіла постає під впливом ідеї про детермінацію приналежності до чоловічого чи жіночого ґендеру даними від народження статевими біологічними ознаками. Внаслідок ґендерного підходу акцентувались такі бінарні опозиції, як маскулінне-фремінне, раціональне-ірраціональне, вище-нижче. Зміст концепту сексуального тіла відображає переконання у небезпечному характері сексуальності. Останню визнають суттєвою загрозою окремим індивідам і соціальному порядку в цілому. Переосмислюється статус сексуального тіла, артикулюються практики його експлуатації та дисциплінування в умовах суспільства споживання. Феміністичний дискурс аналізує концепт ґендеру у фокусі теми сексуальності. Цей концепт має свої виміри: сексуальне насилля, аборти, проституція, соціальне наснаження. Вивчається досвід жінок в області «підтримки» свого тіла (фітнес, мода, дієта тощо). Розглядаються протиріччя, як і породжує безпрецедентне поширення косметичної хірургії, не дивлячись на ризики і небезпеки, які вона несе.

У зв'язку з критичним переглядом початкової ідеї про природність і незмінність статі, нового розуміння набуває сексуальність. Сучасна дослідниця М. Маєрчик вказує на три обставини, які змусили критично переглянути початкову ідею про природність і незмінність статі. Перша обставина полягає в тому, що бінарна структура статі виявилась не універсальною - у різних культурах трапляються дещо відмінні варіанти статевої організації. Другою обставиною стало свідчення, що людські тіла не є строго статево диморфічними, тобто не всі люди можуть бути чітко співвіднесені з однією з двох статевих груп: або жіночою, або чоловічою, - деякі 3 них мають ознаки одночасно обох статей. Третя обставина полягала в тому, що гендерна ідентичність деяких людей не пов'язана з їхніми геніталіями і хромосомною будовою в тій послідовності або закономірності, що встановлена культурою. На основі їхніх геніталій їм приписували стать, з якою самі люди, дорослішаючи, не ідентифікували себе. Про таких людей ще кажуть, що вони «хочуть змінити стать» [13, с. 24].

Розвиток медицини призвів до всеохопного соціального контролю над тілом людини, встановив поняття про норму та аномалію. У зв'язку з піднесенням біотехнологій відкриваються незнані раніше можливості конструювання людського тіла, впливу на генетику людини. Задіяність у владні відносини медичного порядку акцентується у концепції медикалізованого тіла, яка є однією з центральних у феміністичних студіях. Концепт «медикалізованого тіла» уособлює підпорядкованість біологічного (sex) соціальному (gender). Прикладом медикалізації жіночого тіла може слугувати посилення контролю над репродуктивною поведінкою жінок, інституційне регулювання материнських практик шляхом медикалізації (антибіотики, наркоз тощо). Внаслідок влади медичного дискурсу, на думку О. Стрельник, «вагітність сприймають як діагноз (саме так її позначають у медичній документації), що апріорі потребує медичного контролю, а інформаційна асиметрія між лікарем-експертом і жінкою сприяє комерціалізації репродуктивної медицини» [14, с. 22]. 3 точки зору фемінізму причиною подібної ситуації $\epsilon$ те, що «гінекологія і все, що її супроводжує, включаючи контроль над народжуваністю... нерозривно зв'язані з «патріархатом» і мають на увазі владу чоловіка над жінкою, що здійснюється через контроль над жіночими тілами, їх сексуальністю і репродуктивним потенціалом» [15, с. 42]. Такий стан речей у медицині зумовлений також і рудиментарним сприйняттям тіла як машини, а не як соціальної сутності. Подібне тлумачення тіла (картезіанське) зустрічаємо у Декарта та, переважно, в усій класичній західноєвропейській фрілософській традиції.

На відміну від попереднього, концепт гротескного тіла ототожнювався 3 інстинктами, бажаннями, потягами, втіленням яких вважалась жінка. Показово, що саме жіноче тіло під впливом патріархатних установок, що панують у суспільній свідомості, на противагу класичному завершеному тілу (чоловічому), сприймалось виключно крізь призму біологічних актів, в які воно задіяне: статеві зносини, вагітність, народження тощо. Жодне тіло не існує за межами процесів соціального та культурного конструювання значення. У сучасному світі з'являється все більше жінок, які страждають на харчові розлади, процес (не-)прийому їжі $є$ центральним елементом, ідентичності, точніше - елементом руйнівним для ідентичності. Культурна основа харчових розладів $€$ анорексія, яка ще сто років тому була майже невідомою, але сьогодні, разом із хронологічно більш пізньою булемією, вона досягає майже епідемічних масштабів. Харчові розлади можна тлумачити як протест проти визначених норм «жіночності» та розподілу ролей, 
оскільки «практично кожна специфічна риса «базової психопатології» харчових розладів була реконструйована з метою розкриття ще більш поширеного культурного розладу» [16, с. 55].

Уявну повноту анорексички можна розуміти як фантомне (жирове) тіло. Вона поводиться із цією «ампутованою» (жіночною/материнською) частиною як із чужим загрозливим об'єктом. Таким чином, відбувається відокремлення свого Я від тіла, причому лінія відокремлення проходить крізь саме тіло. «Злоякісна» частина тіла, жир, приноситься в жертву задля збереження індивідуальності (й автономії) [17, с. 170-220]. Саме тіло проживається, точніше використовується, як об'єкт: у процесах формування симптомів з морфологічної групи анорексії - в об'єктивних трансформаціях тіла або ж у поводженні з харчуванням - втілюються конфрліктні психічні операції та франтазії [18, с. 187].

Висновки. Здійснений аналіз феміністичних студій як сукупності текстів дозволяє розкрити їх знаково-символічну структуру, визначити ключові концепти як знаки чи культурні коди, що формуються в соціокультурному та історичному полі тексту і несуть символічне, етичне та аксіологічне навантаження. Ґендерний дискурс займає вагоме місце у феміністичних дослідженнях, набуваючи втілення у дискусіях щодо тіла, сексуальності, ідентичності.

Розрізнення статі і ґендеру означало перехід від традиції пояснювати культурні відмінності між жінками і чоловіками біологічними чинниками до можливості пояснювати цю різницю соціальними й культурними детермінантами. 3 поміж багатьох культурних кодів саме концепт ґендеру, як один з багатьох культурних кодів, втілив складну взаємодію природи і суспільства, щоразу наповнюючись новим значенням, розширюючи свої змістові конотації в конкретних культурно-історичних реаліях. Зміст гендеру розкривався через аналіз системи міжособистісної взаємодії, що контролюється суспільством і відтворює уявлення про чоловіче і жіноче як категорії соціального, а не біологічного порядку. Концепти ґендеру і статі стали відображенням емоційного та логічного змісту феміністської дискусії щодо ролі біології в конституюванні ґендерних відмінностей.

Змістовна спрямованість сучасних фреміністичних дискусій зміщується з обговорення абстрактних опозицій природного і соціального в людині до аналізу механізмів панування i гноблення, пов'язаних зі статевими рольовими установками особистості. Виявлено нові смислові відтінки концептів ґендеру та статі завдяки феміністській увазі до феномену тіла, який тривалий час перебував поза соціогуманітарним дискурсом. Потреба пізнання тіла як багатоаспектного смислового утворення, що відображає не лише біологічне, а й культурне, соціальне, історичного зумовила трансформацію філософського, релігійного, медичного дискурсу і дозволила по-новому осягнути співвідношення природи та культури, чоловічності та жіночності, духу та плоті, ґендеру та статі. Модифрікація концептуального поля сучасних феміністичних досліджень ґрунтується на розширенні аксіологічного потенціалу ґендеру, набутті ним нових міждисциплінарних вимірів.

Подальший аналіз концептосфери понять ґендеру та статі в фреміністських студіях надає широкі можливості для конструювання картини соціальної дійсності та переосмислення культури. Одночасно, він відкриває нові проблемні питання, вирішення яких передбачає зміну ціннісних орієнтирів і перегляд багатьох усталених соціокультурних уявлень.

Література

1.Афанасьєва, О. Теоретичні засади феміністичних напрямків: до проблеми типології / О. Афанасьєва // Вісн. Черкас. ун-ту. Сер. Філол. науки. - 2011. - Вип. 198. - С. 24-31.

2.Храброва, Г. М. Особливості діалогу феміністичних досліджень і літературознавчого дискурсу / Г. М. Храброва // Держава та регіони. Серія : Гуманітарні науки. - 2013. - № 2-3. - С. 18-24.

3. Beauvoir, S. de. Le deuxième sexe. Tome II : L'expérience vécue [1949] / Simone de Beauvoir. - Paris, Gallimard, 1976.

4.Goffman, E. Gender Display, in C.Lemert and A.Branaman, eds., Goffman Reader. - Oxford, Blackwell Publ., 1997.

5.Sayers, J. Biological Politics. Feminism and Anti-Feminist Perspectives. N. Y., 1986.

6. Man-Made Medicine. Women's Health, Public Policy and Reform / Ed. by K. L. Moss. Duke University Press, 1996. (Man-Made Medicine, 1996, p. 20.)

7.Scully, D. Men Who Control Women's Health. The Miseducation of Obstetricians-Gynecologists. N. Y., 1994.

8. Bobylore / Ed. by K. Young. Knoxville, 1995.

9. Зборовська, Н. Феміністичні роздуми на карнавалі мертвих поцілунків / Н. Зборовська, М. Ільницька. - Л. : Літопис, 1999. $-336 \mathrm{c}$.

10. Embodied Practices. Feminist Perspectives of the Body. L., 1997. 1999.

11. LeCroy, C. W. Empowering Adolescent Girls. N.Y., 2001. P. 26.Birke L. Feminism and Biological Body. Edinburgh, 
12. Birke, L. (1999). Feminism and Biological Body. Edinburgh (in English)

13. Hatty, S. The Disordered Body: Epidemic Disease and a Cultural Transformation. N.Y., 1999.

14. Маєрчик, М. Гендер і стать: від бінарності до багатоманіття (Розділ 1) // Гендер для медій: підручник із гендерної теорії для журналістики та інших соціогуманітарних спеціальностей / за ред. М. Маєрчик, О. Плахотнік, Г. Ярманової [3 видання, випр. і доп.]. - К.: Критика, 2017. - С. 11-27.

15. Стрельник, О. Турбота як робота: материнство у фокусі соціології. Монографрія. - Київ: Критика, 2017 [КНУ ім. Т. Шевченка; факультет соціології]. - 280 с.

16. Pringle, R. Sex and Medicine. Gender, Power and Authority in the Medical Profession. Cambridge, 1998

17. Bordo, S. Unbearable Weight. Feminism, Western Culture and the Body. Berkeley: University of California Press, 1993.

18. Willenberg, H. Mit Leib und Seel' und Mund und Händen. Der Umgang mit der Nahrung, dem Körper und seinen Funktionen bei Patienten mit Anorexia nervosa und Bulimia nervosa. In: M. Hirsch. Der eigene Körper als Objekt. Zur Psychodynamik selbstdestruktiven Körperagierens - Gießen: Psychosozial-Verlag, 1998.

\section{References}

1.Afanasieva, O. (2011). Teoretychni zasady feministychnykh napriamkiv: do problemy typolohii [Theoretical foundations of feminist directions: on the problem of typology]. Visn. Cherkas. un-tu. Ser. Filol. nauky - Herald of Cherkasy University. Series: Philological Sciences, 198, 24-31 [in Ukrainian].

2. Khrabrova, H. M. (2013). Osoblyvosti dialohu feministychnykh doslidzhen i literaturoznavchoho dyskursu [Features of the Dialogue of Feminist Studies and Literary Discourse]. Derzhava ta rehiony. Seriia: Humanitarni nauky - State and Regions. Series: Humanities, 2-3, 18-24 [in Ukrainian].

3. Beauvoir, S. de. (1976). Le deuxième sexe. (Tome II: L'expérience vécue). Paris: Gallimard [in French].

4.Goffman, E. (1997). Gender Display. C. Lemert and A. Branaman (Eds.). Goffman Reader. (pp. 208-227). Oxford, Blackwell Publ [in English].

5.Sayers, J. (1986). Biological Politics. Feminism and Anti-Feminist Perspectives. New York [in English].

6. Moss, K. L. (Eds.). (1996). Man-Made Medicine. Women's Health, Public Policy and Reform. Duke University Press [in English].

7.Scully, D. (1994). Men Who Control Women's Health. The Miseducation of Obstetricians-Gynecologists. (pp. 48-52). New York [in English].

8. Young, K. (Eds.). (1995). Bobylore. (P. XVII). Knoxville [in English].

9.Zborovska, N., Inytska, M. (1999). Feminist Thoughts on the Carnival of Dead Kisses [Feminist reflections on the carnival of dead kisses]. Lviv: Litopys [in Ukrainian].

10. Embodied Practices. Feminist Perspectives of the Body. (1997). London [in English].

11. LeCroy, C. W. (2001). Empowering Adolescent Girls. New York [in English].

12. Birke, L. (1999). Feminism and Biological Body. Edinburgh [in English].

13. Hatty, S. (1999). The Disordered Body: Epidemic Disease and a Cultural Transformation. New York [in English].

14. Maierchyk, M. (2017). Gender and sex: from binary to multivariate (Section 1) [Hender i stat: vid binarnosti do bahatomanittia (Rozdil 1)]. In Gender for the media: a textbook on gender theory for journalism and other socio-humanities specialties - Hender dlia medii: pidruchnyk iz hendernoi teorii dlia zhurnalistyky ta inshykh sotsiohumanitarnykh spetsialnostei. M. Maierchyk, O. Plakhotnik, H. Yarmanova (Eds.). (3rd ed., rev.). (pp. 11-27). Kyiv: Krytyka [in Ukrainian].

15. Strelnyk, O. (2017). Caring as work: motherhood in the focus of sociology [Turbota yak robota: materynstvo u fokusi sotsiolohii]. Kyiv: Krytyka [in Ukrainian].

16. Pringle, R. (1998). Sex and Medicine. Gender, Power and Authority in the Medical Profession. Cambridge [in English].

17. Bordo, S. (1993). Unbearable Weight. Feminism, Western Culture and the Body. Berkeley: University of California Press [in English].

18. Willenberg, H. (1998). Mit Leib und Seel' und Mund und Händen. Der Umgang mit der Nahrung, dem Körper und seinen Funktionen bei Patienten mit Anorexia nervosa und Bulimia nervosa. M. Hirsch. Der eigene Körper als Objekt. Zur Psychodynamik selbstdestruktiven Körperagierens (ss. 170-220). Gießen: Psychosozial-Verlag [in German].

Надійшла 03.04.2019

Бібліографічний опис для цитування :

Ковальчук, Н. Д. Конотації концептів ґендеру і статі у феміністичних студіях / Н. Д. Ковальчук, Н. В. Шакун, О. Є. Мельник // Проблеми соціальної роботи: фрілософрія, психологія, соціологія. - 2019 - № 1 (13) - С. 13-20. 